NASA/TM-2012-217233

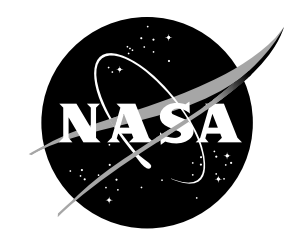

\title{
Thermal Vacuum Integrated System Test at B-2
}

Maureen T. Kudlac and Harold F. Weaver

Glenn Research Center, Cleveland, Ohio

Mark D. Cmar

Sierra Lobo, Inc., Fremont, Ohio 


\section{NASA STI Program . . . in Profile}

Since its founding, NASA has been dedicated to the advancement of aeronautics and space science. The NASA Scientific and Technical Information (STI) program plays a key part in helping NASA maintain this important role.

The NASA STI Program operates under the auspices of the Agency Chief Information Officer. It collects, organizes, provides for archiving, and disseminates NASA's STI. The NASA STI program provides access to the NASA Aeronautics and Space Database and its public interface, the NASA Technical Reports Server, thus providing one of the largest collections of aeronautical and space science STI in the world. Results are published in both non-NASA channels and by NASA in the NASA STI Report Series, which includes the following report types:

- TECHNICAL PUBLICATION. Reports of completed research or a major significant phase of research that present the results of NASA programs and include extensive data or theoretical analysis. Includes compilations of significant scientific and technical data and information deemed to be of continuing reference value. NASA counterpart of peer-reviewed formal professional papers but has less stringent limitations on manuscript length and extent of graphic presentations.

- TECHNICAL MEMORANDUM. Scientific and technical findings that are preliminary or of specialized interest, e.g., quick release reports, working papers, and bibliographies that contain minimal annotation. Does not contain extensive analysis.

- CONTRACTOR REPORT. Scientific and technical findings by NASA-sponsored contractors and grantees.
- CONFERENCE PUBLICATION. Collected papers from scientific and technical conferences, symposia, seminars, or other meetings sponsored or cosponsored by NASA.

- SPECIAL PUBLICATION. Scientific, technical, or historical information from NASA programs, projects, and missions, often concerned with subjects having substantial public interest.

- TECHNICAL TRANSLATION. Englishlanguage translations of foreign scientific and technical material pertinent to NASA's mission.

Specialized services also include creating custom thesauri, building customized databases, organizing and publishing research results.

For more information about the NASA STI program, see the following:

- Access the NASA STI program home page at http://www.sti.nasa.gov

- E-mail your question via the Internet to help@ sti.nasa.gov

- Fax your question to the NASA STI Help Desk at $443-757-5803$

- Telephone the NASA STI Help Desk at 443-757-5802

- Write to: NASA Center for AeroSpace Information (CASI) 7115 Standard Drive Hanover, MD 21076-1320 
NASA/TM-2012-217233

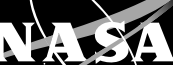

Thermal Vacuum Integrated System Test at B-2

Maureen T. Kudlac and Harold F. Weaver

Glenn Research Center, Cleveland, Ohio

Mark D. Cmar

Sierra Lobo, Inc., Fremont, Ohio

Prepared for the

24th Space Cryogenics Workshop

sponsored by the NASA Marshall Space Flight Center and NASA Kennedy Space Center Coeur D’Alene, Idaho, June 8-10, 2011

National Aeronautics and

Space Administration

Glenn Research Center

Cleveland, Ohio 44135 
Level of Review: This material has been technically reviewed by technical management.

Available from

NASA Center for Aerospace Information

7115 Standard Drive

Hanover, MD 21076-1320
National Technical Information Service 5301 Shawnee Road Alexandria, VA 22312

Available electronically at http://www.sti.nasa.gov 


\title{
Thermal Vacuum Integrated System Test at B-2
}

\author{
Maureen T. Kudlac and Harold F. Weaver \\ National Aeronautics and Space Administration \\ Glenn Research Center \\ Cleveland, Ohio 44135 \\ Mark D. Cmar \\ Sierra Lobo, Inc. \\ Fremont, Ohio 43420
}

\begin{abstract}
The National Aeronautics and Space Administration (NASA) Glenn Research Center (GRC) Plum Brook Station (PBS) Space Propulsion Research Facility, commonly referred to as B-2, is NASA's third largest thermal vacuum facility. It is the largest designed to store and transfer large quantities of liquid hydrogen and liquid oxygen, and is perfectly suited to support developmental testing of chemical propulsion systems as well as fully integrated stages. The facility is also capable of providing thermalvacuum simulation services to support testing of large lightweight structures, Cryogenic Fluid Management (CFM) systems, electric propulsion test programs, and other In-Space propulsion programs.

A recently completed integrated system test demonstrated the refurbished thermal vacuum capabilities of the facility. The test used the modernized data acquisition and control system to monitor the facility during pump down of the vacuum chamber, operation of the liquid nitrogen heat sink (or cold wall) and the infrared lamp array. A vacuum level of $1.3 \times 10^{-4} \mathrm{~Pa}\left(1 \times 10^{-6}\right.$ torr $)$ was achieved. The heat sink provided a uniform temperature environment of approximately $77 \mathrm{~K}\left(140{ }^{\circ} \mathrm{R}\right)$ along the entire inner surface of the vacuum chamber. The recently rebuilt and modernized infrared lamp array produced a

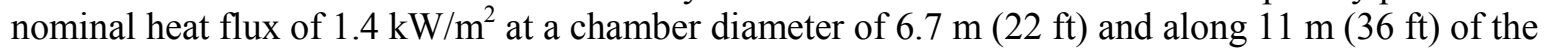
chamber's cylindrical vertical interior. With the lamp array and heat sink operating simultaneously, the thermal systems produced a heat flux pattern simulating radiation to space on one surface and solar exposure on the other surface. The data acquired matched pretest predictions and demonstrated system functionality.
\end{abstract}

\section{Introduction}

Due to the thermal extremes in space, the hardware designer faces a unique set of challenges. Preflight developmental testing is essential to mission success. B-2 was designed in the 1960 s to meet the challenge of testing upper-stages launch vehicles and rocket engines across their entire operational environment by simulating the pressure and thermal environment (Ref. 1). In addition to testing upperstages and engines, B-2 is also used as a thermal vacuum chamber. In 2006, an effort was undertaken to incrementally refurbish and modernize the facility systems (Ref. 2). As the major facility systems are refurbished, an integrated systems test (IST) is performed. The purpose an IST is to demonstrate facility operation and performance. An IST also provides the facility staff an opportunity to gain hands on operational experience with the refurbished systems without the presence of a test article.

At the center of the B-2 complex is a large vertical vacuum chamber consisting of a cylindrical section that is $11.5 \mathrm{~m}(38 \mathrm{ft})$ diameter by $14 \mathrm{~m}(46 \mathrm{ft})$ high topped with a hemispherical head of the same diameter. Below the cylindrical portion of the chamber is a $3.4 \mathrm{~m}(11 \mathrm{ft})$ diameter by $11.3 \mathrm{~m}(37 \mathrm{ft})$ long exhaust duct sealed with at its lower extreme with a high vacuum valve. Typical test article installation into the test chamber is via a hinged hatch at the top of the hemispherical dome using an $18,100 \mathrm{~kg}$ ( 20 ton) overhead crane. The hatch is $8.2 \mathrm{~m}(26.75 \mathrm{ft})$ in diameter. The nominal test article envelope is $6.7 \mathrm{~m}(22 \mathrm{ft})$ diameter by $15.8 \mathrm{~m}(52 \mathrm{ft})$ maximum vertical clearance. Personnel and small equipment 


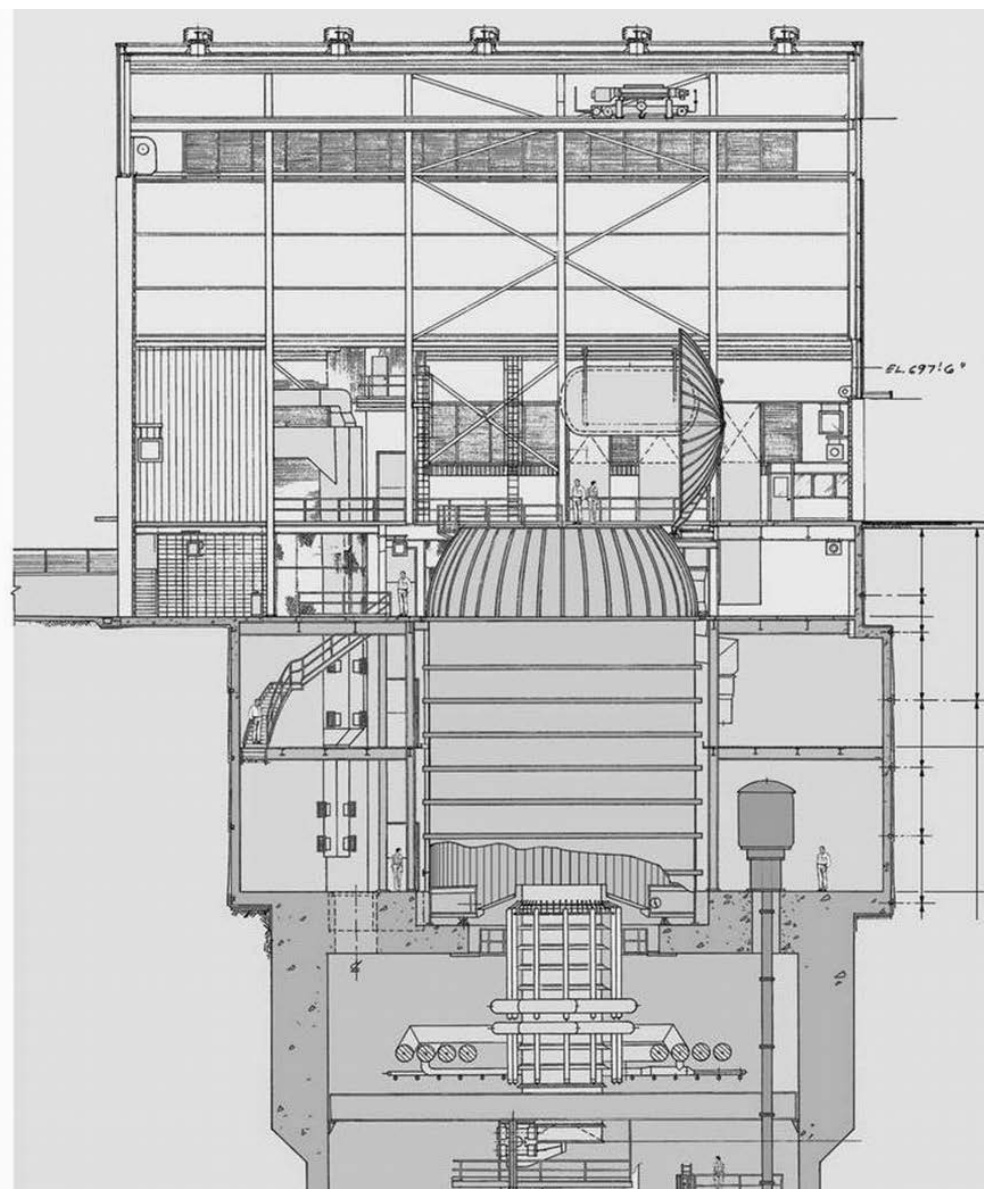

Figure 1.-Artist's rendering of the B-2 test building. The vacuum chamber is shown in the center with the top access hatch open. The diffuser duct and $3.4 \mathrm{~m}$ valve are visible at the bottom of the chamber. An $\mathrm{LN}_{2}$ tank that supplies the cold wall is visible next to the open top access hatch.

access is available via 1.8 meter (6 ft) diameter circular doors located at the bottom of the chamber and at 12.5 meters $(41 \mathrm{ft})$ above the bottom of the chamber. Numerous high-vacuum penetrations exist at multiple elevations for routing of fluids and electrical power, or signals internal to the chamber without compromising the vacuum environment. A cross-section elevation view of the test chamber is shown in Figure 1.

Ultimate vacuum conditions are achieved via ten $0.89 \mathrm{~m}(2.9 \mathrm{ft})$ diameter oil diffusion pumps with integral (water) cold caps. These cold caps are cooled to approximately $280 \mathrm{~K}\left(504^{\circ} \mathrm{R}\right)$ by a chilled glycol system to further condense diffusion pump oil and minimize backstreaming rates.

Thermal simulation of near earth space conditions within the test chamber is accomplished via a liquid nitrogen heat sink (also called a cold wall) and an infrared lamp array.

The liquid nitrogen heat sink lines the entire interior of the test chamber, producing a final chamber interior clear diameter of $10.4 \mathrm{~m}(34 \mathrm{ft})$ and height envelope of $17 \mathrm{~m}(56 \mathrm{ft})$ on chamber centerline. Coverage includes the top access hatch, which has a separate liquid nitrogen heat sink attached. The only portion of the chamber not having integrated heat sink coverage is a $6.7 \mathrm{~m}(22 \mathrm{ft})$ diameter circle on the floor level of the chamber. Figure 2 shows a picture of the cold wall installed in the chamber. 


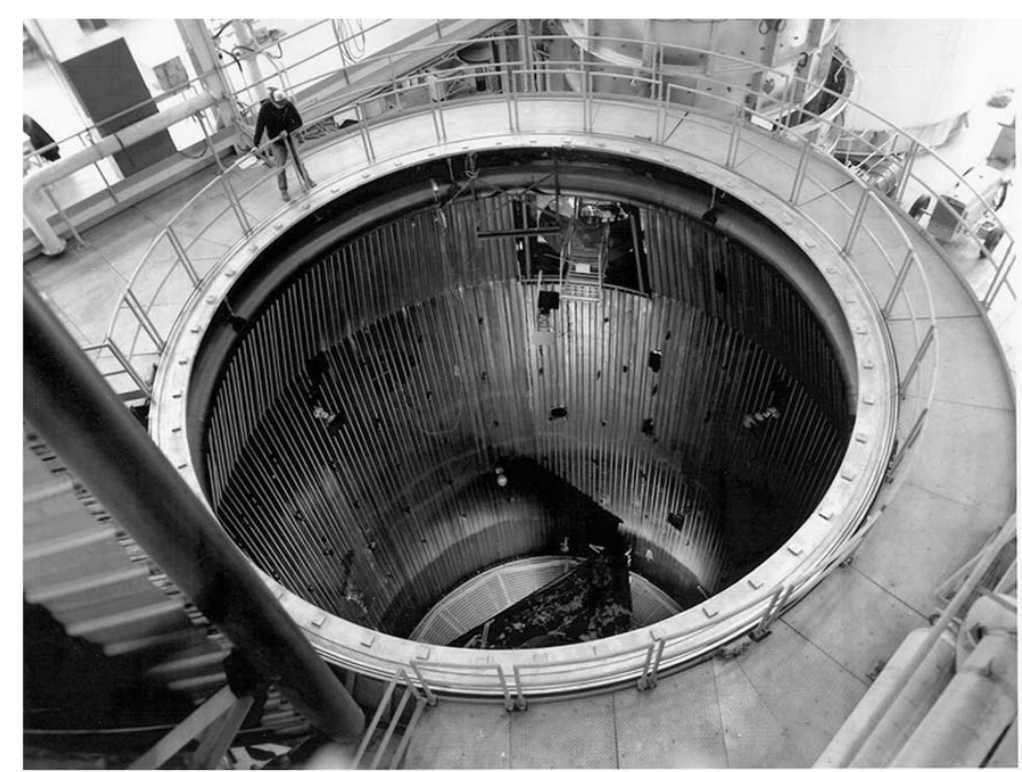

Figure 2.-View into the B-2 vacuum chamber. The upper personnel door is visible along the back wall of the chamber.

The cold wall body and top cap are flooded with liquid nitrogen that is gravity-fed from a tank located above the vacuum chamber into a supply manifold located at the base. The cold wall consists of tube-in-strip panel arrangement resulting in an optically dense surface. The heat sink provides a uniform temperature environment of approximately $77 \mathrm{~K}\left(139^{\circ} \mathrm{R}\right)$. The cold wall is made of copper to optimize thermal conduction.

The infrared lamp array is designed to produce a heat flux pattern on the test article simulating solar exposure on one side of a test article. Currently, the array is configured with twelve individually controllable "zones". Each zone consists of a vertical column of tungsten quartz infrared lamps spanning from the test chamber floor to a height of $11 \mathrm{~m}$ (36 ft) above floor level containing forty-eight $0.75 \mathrm{~kW}$ lamps, for a zone power of $36 \mathrm{~kW}$ and a total array power of $432 \mathrm{~kW}$. Lamp power is supplied by twelve zone power controllers that are rated at $50 \mathrm{~kW}$ and an array capacity of $600 \mathrm{~kW}$.

The twelve columns are distributed over a $109^{\circ}$ arc of the test chamber circumference. The array can be controlled to provide a sinusoidal distribution of the flux pattern on the test article or other pattern as required. The radiant heat flux at the nominal test article radial envelope of $6.7 \mathrm{~m}(22 \mathrm{ft})$ diameter is $1.4 \mathrm{~kW} / \mathrm{m}^{2}$. Other mounting points exist for locating reflector columns at other circumferential locations within the chamber.

Test operations are conducted in a separate building, B-Control, which is located $777 \mathrm{~m}(2,550 \mathrm{ft})$ west of the test building. The state of the art controls system is a programmable logic controller (PLC) based system with a graphical user interfaces (GUI). In addition to providing facility control, the control system is used to monitor facility ancillary systems, and keep a log of key parameters. All control signals between the control room and the test facility are transmitted via a fiber optic network. The control room is shown in Figure 3.

All test data acquired is digitized in the data room located at the test facility. The resulting data is streamed immediately via fiber optics to redundant data storage arrays that are located at the B-Control building. The network does not introduce any appreciable time delay between data acquisition at the test facility and transmission to B-Control. The system can acquire low speed data up to $4000 \mathrm{samples} / \mathrm{sec}$. (The high speed channels can record data at 256,000 samples/sec.) Slower sampling rates are also achievable and set typically at $125 \mathrm{samples} / \mathrm{sec}$. After the data has been recorded, it is then post processed where data graphs and files are generated for customer review. 


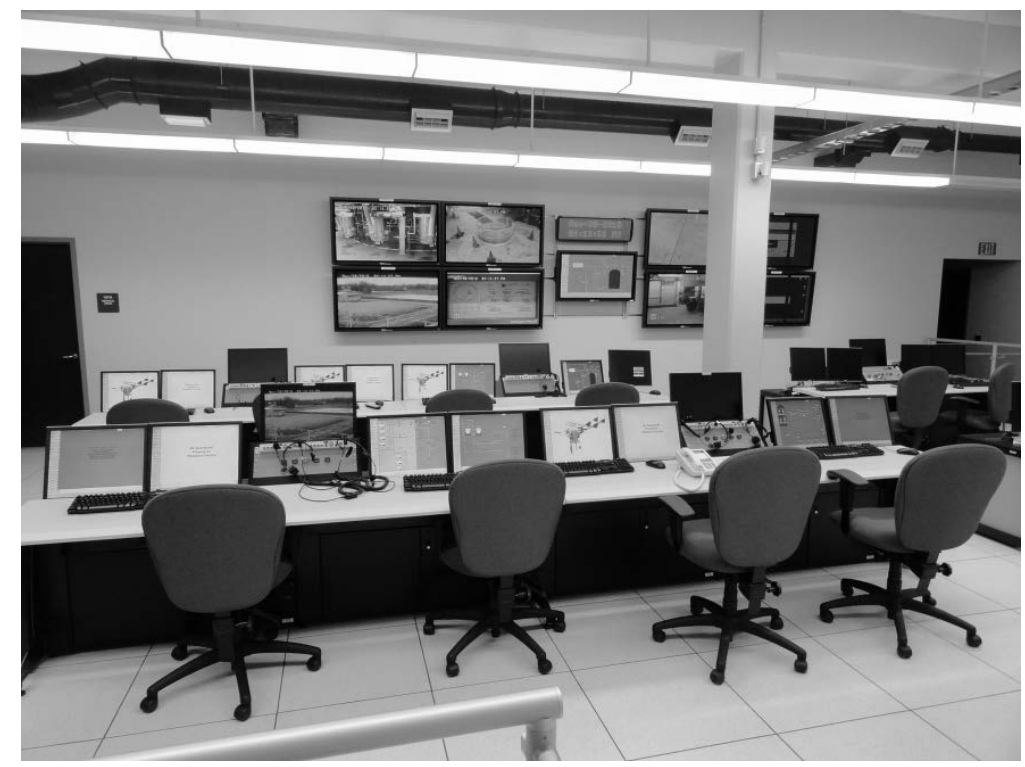

Figure 3.-The modernized control room for B-2. Graphical user interfaces (GUI) for the programmable logic control (PLC) based system are visible in the foreground. Along the back wall, video monitors display test site camera images.

\section{Materials and Methods}

The purpose of this integrated system test (IST) was to demonstrate the interoperability of the facility thermal vacuum systems. The facility thermal simulation systems have not been operated in a number of years. Prior to operation, the liquid nitrogen system was refurbished and the electronics for the infrared lamp array were modernized.

For the IST, three zones of the solar array were installed in the chamber. A test article consisting of a rounded panel (simulating the rounded surface of a tank wall) was located $3.7 \mathrm{~m}(12 \mathrm{ft})$ above the vacuum chamber floor (see Figs. 4 and 5). The test article was instrumented with thermocouples and heat flux sensors. Two heat flux sensors were mounted on the test article surface to measure the radiant heat flux into and out of the test article. The other two heat flux sensors were mounted above the test article to measure the flux from the lamp array. Additionally, thermocouples were placed at three elevations in the vacuum chamber: $3.7 \mathrm{~m}(12 \mathrm{ft}), 7.3 \mathrm{~m}(24 \mathrm{ft})$, and $11 \mathrm{~m}(36 \mathrm{ft})$. At each elevation five thermocouples were spaced equidistantly across the vacuum chamber diameter. The thermocouples were placed to obtain thermal stratification data inside the vacuum chamber.

Following installation of the test article and instrumentation, the lamp array was powered and checked out at atmospheric pressure. The vacuum chamber was then secured and pumped down below $0.13 \mathrm{~Pa}\left(1 \times 10^{-3}\right.$ torr $)$ and the lamps were activated and checked out under vacuum conditions. The lamp power was ramped from 0 to full power in four steps with a power dwell of 4 min at each power interval. A second test with only one infrared lamp column powered was then conducted. The array was operated in both manual and automatic mode.

Fill of the liquid nitrogen heat sink (cold wall) followed vacuum testing of the lamp array. During the fill of the cold wall body, flow was periodically terminated and the system allowed to reach equilibrium. The purpose of partially filling the cold wall was to determine the ability to provide other background temperatures in the chamber.

The lamp array was then activated with the liquid nitrogen heat sink flooded. The lamp arrays were once again ramped 0 to full power in four steps with a power dwell of four minutes at each power level. The liquid nitrogen heat sink was drained and the vacuum chamber re-pressurized. 


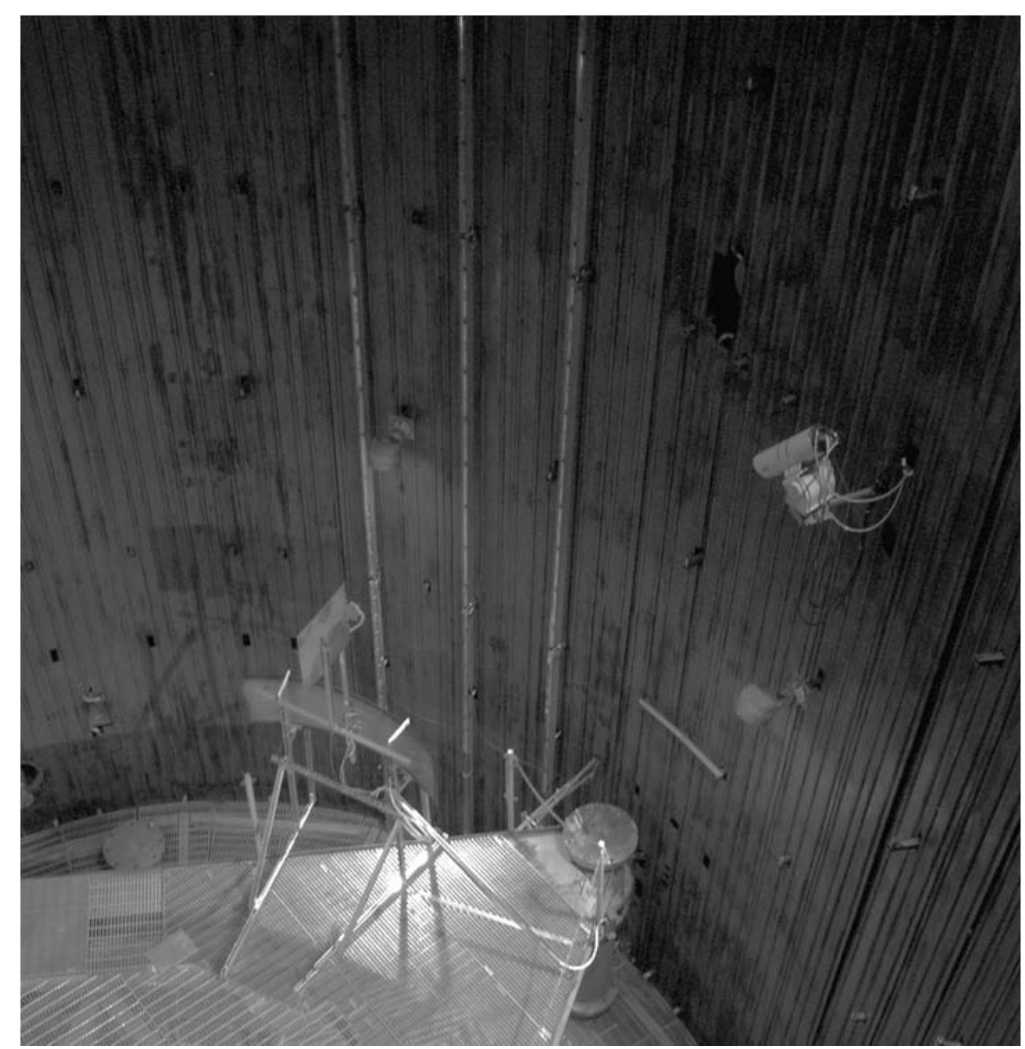

Figure 4.-The simulated test article installed in the vacuum chamber. Three (3) vertical infrared lamp arrays are visible along the back wall.

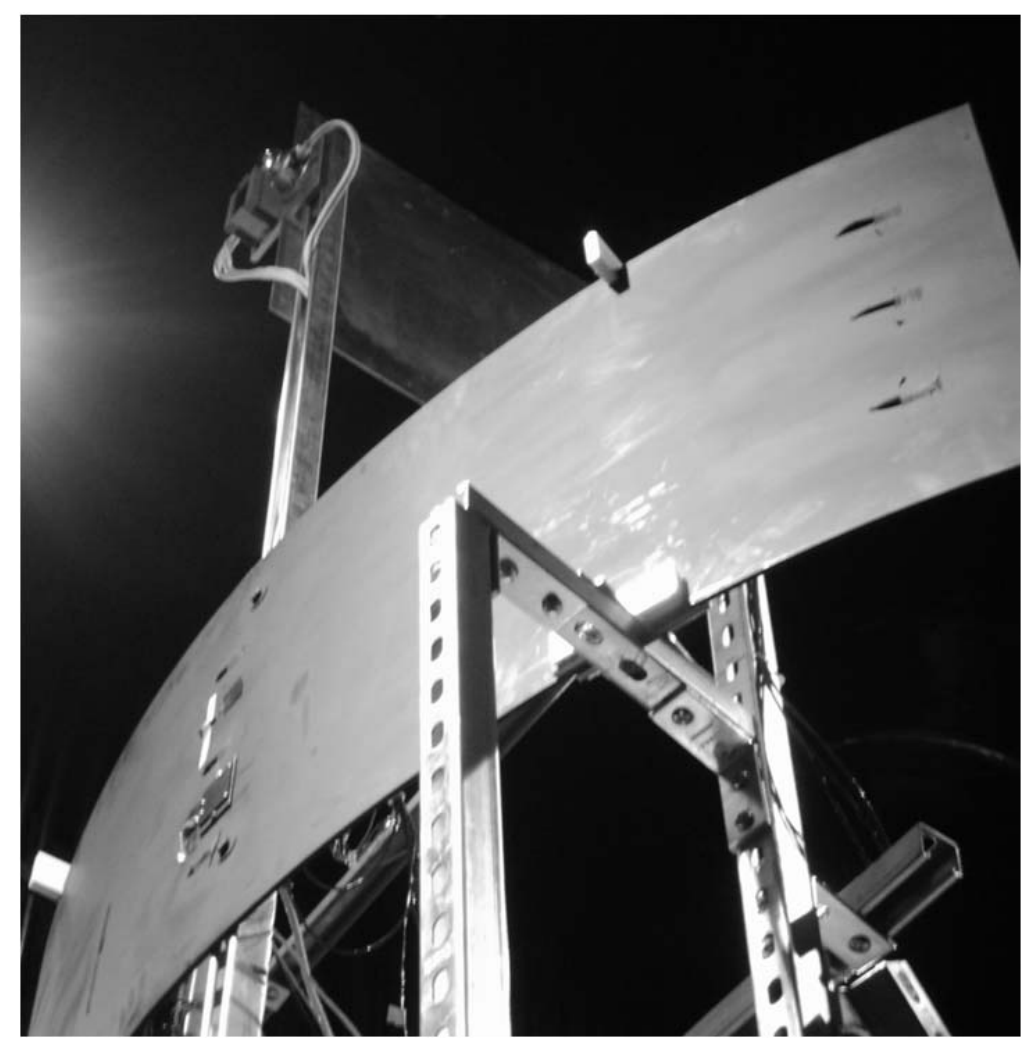

Figure 5.-A close up of the simulated test article. 


\section{Results and Discussion}

Pretest predictions were that levels of $7 \times 10^{-6} \mathrm{~Pa}\left(5 \times 10^{-8}\right.$ torr $)$ would be achieved with the liquid nitrogen heat sink in operation. A camera installed in the vacuum chamber for visualization of the test article was found to have a leak on the purge system. Rather than breaking vacuum to repair the leak, it was decided to continue testing with slightly degraded vacuum level of $9 \times 10^{-4} \mathrm{~Pa}\left(7 \times 10^{-6}\right.$ torr $)$.

Performance of the infrared lamps at vacuum only conditions was controllable in both the automatic and manual modes. Four different heat flux measurement were taken at the test article. The heat flux sensors mounted above the test article provided complementary data but did not precisely agree due to variation in the placement of the instrument and the instrument manufacturer. One of the heat flux sensors was painted black and as expected the measured flux was higher than sensors without the coating. A second sensor on the test article failed (no flux measurement) during operation with the $\mathrm{LN}_{2}$ heat sink. The instrument that failed was not advertised for use in cold environments but was installed to determine if it was suitable. The infrared lamp system was designed to provide a heat flux equal to one solar constant at the test article surface. The flux equivalent to one solar constant is $1.367 \mathrm{~kW} / \mathrm{m}^{2}$ and varies slightly depending upon solar activity (Ref. 3). Test results for the average heat flux 2 sensors are shown in Table 1. (The sensor with the black coating and the sensor that failed during cold exposure were not included in the data set.) When the cold wall is operational, the heat flux on the test article is slightly lower than when the cold wall is at ambient temperature. Reducing the number of lamp columns powered also effect the heat flux on the test article. As can be seen, the infrared lamps provide positive margin for simulating the incident heat flux for near earth solar exposure.

Historic facility documentation stated that cold wall fill took $24 \mathrm{hr}$ to perform. Taking into account the planned flow stoppages, the wall was filled in approximately $4 \mathrm{hr}$ for this test. Some optimization of technique could be performed to balance fill rate versus chilldown losses. During the test it was possible to hold liquid level in the wall and achieve relatively steady state temperature on test article surfaces. The temperature achieved during partial wall fill operations was warmer than the total fill test article steady state temperature. For example, it was possible to maintain $243 \pm 2 \mathrm{~K}$ at the test article with the cold wall partially filled with $\mathrm{LN}_{2}$. Data from this test will be used to validate a thermal model of the cold wall that will allow customers to choose temperatures other than $77 \mathrm{~K}$ as the background temperature based on test article size and position. After the cold wall was completely filled with $\mathrm{LN}_{2}$, the test article reached steady state after approximately $5 \mathrm{hr}$. The radial and vertical temperature gradients in the vacuum chamber are shown in Figures 6 and 7, respectively. The test article temperatures are shown in Figure 8. The temperatures variation at steady state was consistent with the pre-test expectations. There thermal stratification vertically in the wall is consistent with changes in saturation pressure due to the liquid head. The test article reached steady state temperature more quickly than most test articles due to the small thermal mass and lack of insulation.

TABLE 1.-HEAT FLUX AT THE TEST ARTICLE

\begin{tabular}{|l|c|c|c|c|c|}
\hline \multirow{2}{*}{$\begin{array}{c}\text { Thermal-vacuum } \\
\text { condition }\end{array}$} & \multirow{2}{*}{$\begin{array}{c}\text { Columns } \\
\text { powered }\end{array}$} & \multicolumn{4}{|c|}{ Heat flux $\mathrm{kW} / \mathrm{m}^{2}$ lamp power level } \\
\cline { 3 - 6 } & & $25 \%$ & $50 \%$ & $75 \%$ & $100 \%$ \\
\hline Vacuum & 3 & 0.16 & 0.73 & 1.6 & 2.5 \\
Vacuum & 1 & 0.10 & 0.48 & 1.1 & 1.6 \\
Vacuum and cold wall & 3 & 0.09 & 0.47 & 1.1 & 2.0 \\
\hline
\end{tabular}




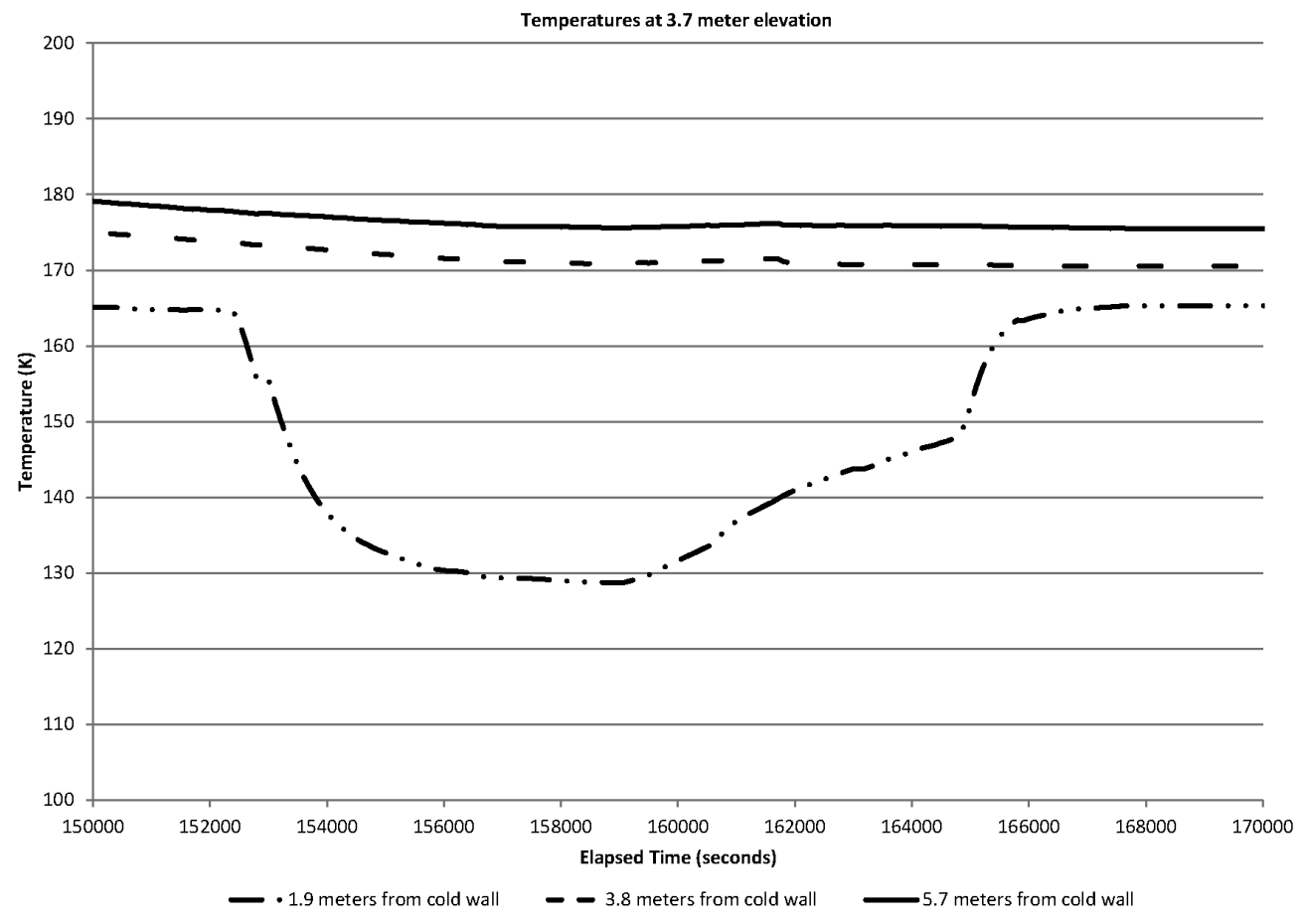

Figure 6.-Radial temperature gradient at $3.7 \mathrm{~m}$ elevation. The temperature drop at $1.9 \mathrm{~m}$ from the cold wall is the result of adding additional liquid to maintain wall fill levels.

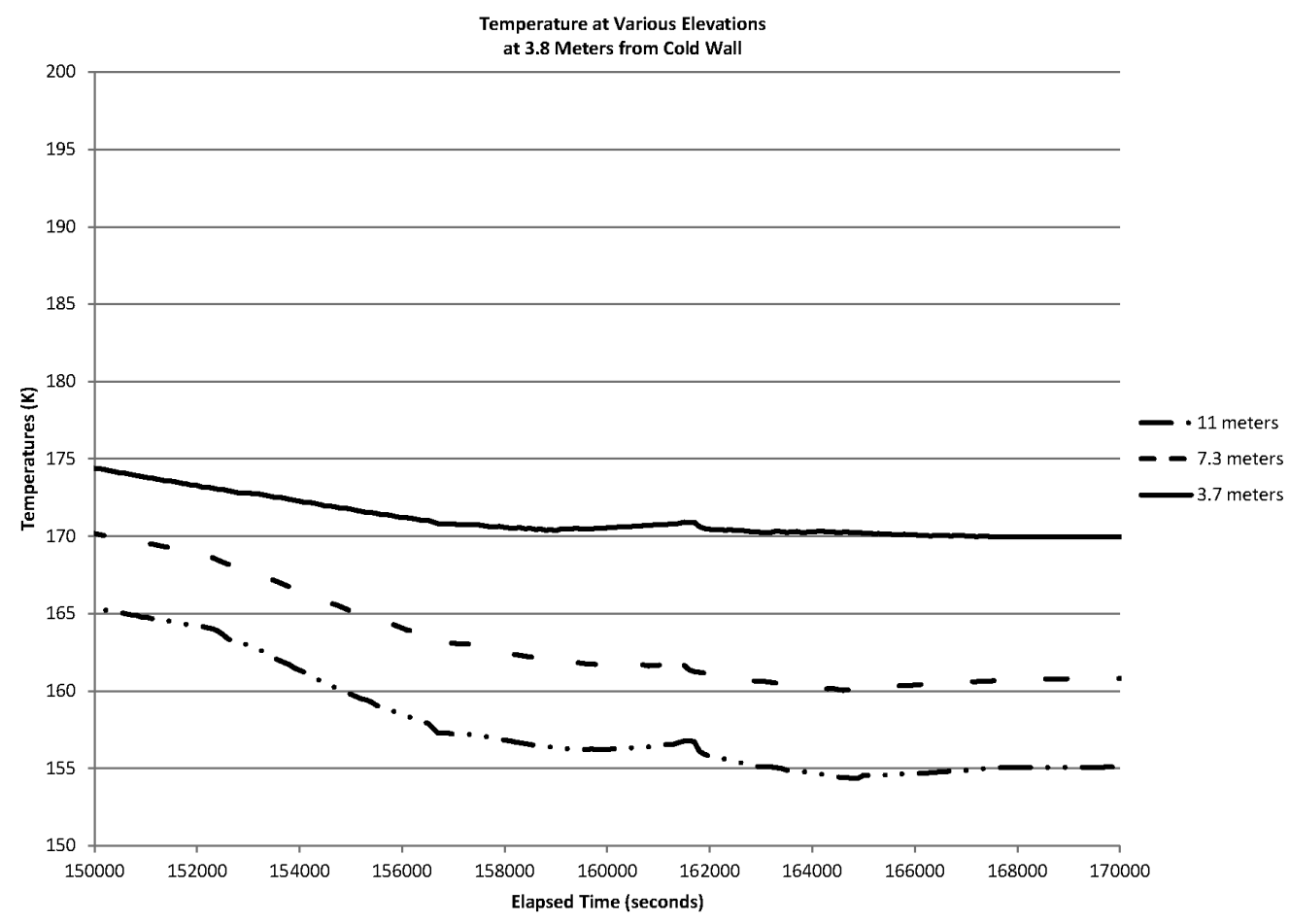

Figure 7.-Vertical temperature gradients at $3.8 \mathrm{~m}$ from the cold wall. 


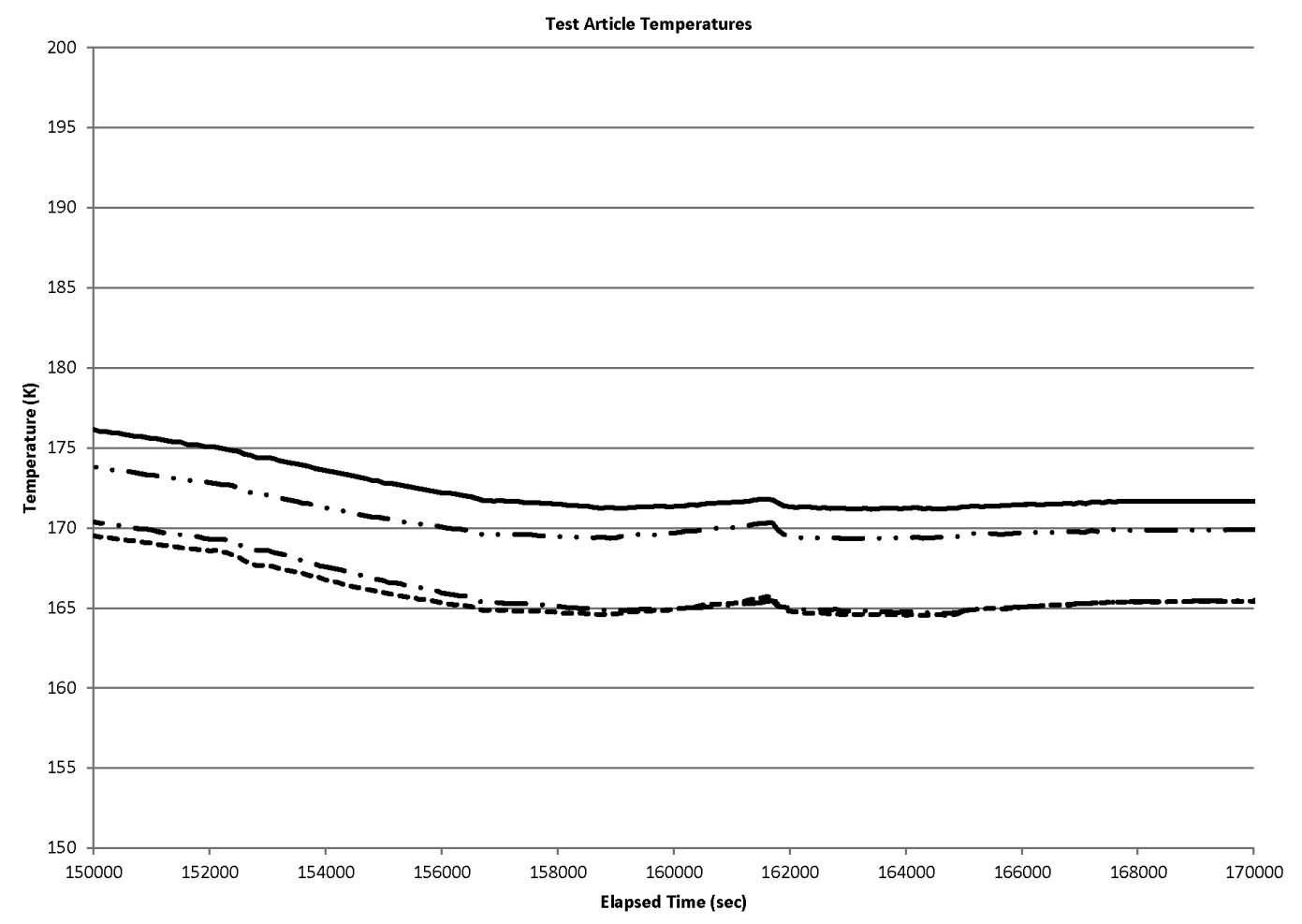

Figure 8.-Test article temperatures with cold wall operational.

\section{Conclusions}

The IST successfully demonstrated the thermal vacuum capabilities of the B-2 facility. Despite a known leak in the vacuum chamber, a pressure level of $9 \times 10^{-4} \mathrm{~Pa}\left(7 \times 10^{-6}\right.$ torr $)$ was achieved. The infrared lamp array produced an incident heat flux in excess of a solar constant. Achieving heat flux equivalent to one solar constant can be achieved by controlling the power level supplied to the lamps or using fewer lamps. The cold wall can be completely flooded to provide approximately $77 \mathrm{~K}\left(140^{\circ} \mathrm{R}\right)$ background temperature for test articles. Partial fill of the cold wall can be used to achieve alternate background temperatures depending upon the test articles sensitivity to thermal gradients along the vertical axis of the chamber.

\section{References}

1. Klein, W.E., Spacecraft Propulsion Research Facility (B-2) at the Lewis Research Center's Plum Brook Station. SAE Paper 931437 presented at the Aerospace Atlantic Conference and Exhibition April 20-23, 1993.

2. Hill, Gerald et al., Space Propulsion Research Facility (B-2): an Innovative Multi-Purpose Test Facility. NASA Technical Memorandum TM-2011-217007 presented at the 26th Aerospace Testing Seminar, Manhattan Beach, CA, March 2011.

3. Zirin, Harold, Encyclopedia Britannica. http://www.britannica.com/EBchecked/topic/552889/solarconstant. Accessed May 2011 



\begin{tabular}{|c|c|c|c|c|c|}
\hline \multicolumn{5}{|c|}{ REPORT DOCUMENTATION PAGE } & $\begin{array}{l}\text { Form Approved } \\
\text { OMB No. 0704-0188 }\end{array}$ \\
\hline \multicolumn{6}{|c|}{ 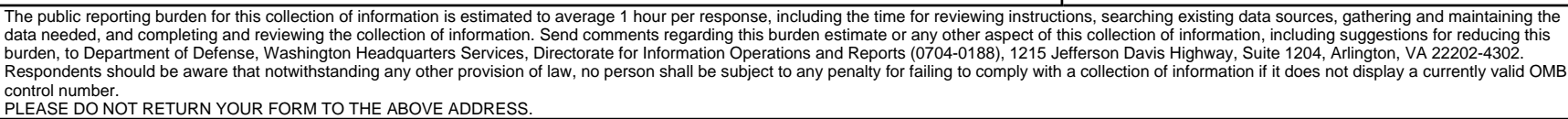 } \\
\hline \multicolumn{2}{|c|}{$\begin{array}{l}\text { 1. REPORT DATE (DD-MM-YYYY) } \\
01-12-2012\end{array}$} & \multicolumn{3}{|c|}{$\begin{array}{l}\text { 2. REPORT TYPE } \\
\text { Technical Memorandum }\end{array}$} & 3. DATES COVERED (From - To) \\
\hline \multirow{3}{*}{\multicolumn{5}{|c|}{$\begin{array}{l}\text { 4. TITLE AND SUBTITLE } \\
\text { Thermal Vacuum Integrated System Test at B-2 }\end{array}$}} & 5a. CONTRACT NUMBER \\
\hline & & & & & 5b. GRANT NUMBER \\
\hline & & & & & 5c. PROGRAM ELEMENT NUMBER \\
\hline \multirow{3}{*}{\multicolumn{5}{|c|}{$\begin{array}{l}\text { 6. AUTHOR(S) } \\
\text { Kudlac, Maureen, T.; Weaver, Harold, F.; Cmar, Mark, D. }\end{array}$}} & 5d. PROJECT NUMBER \\
\hline & & & & & 5e. TASK NUMBER \\
\hline & & & & & $\begin{array}{l}\text { 5f. WORK UNIT NUMBER } \\
\text { WBS } 750271.09 .02 .03\end{array}$ \\
\hline \multicolumn{5}{|c|}{$\begin{array}{l}\text { 7. PERFORMING ORGANIZATION NAME(S) AND ADDRESS(ES) } \\
\text { National Aeronautics and Space Administration } \\
\text { John H. Glenn Research Center at Lewis Field } \\
\text { Cleveland, Ohio 44135-3191 }\end{array}$} & $\begin{array}{l}\text { 8. PERFORMING ORGANIZATION } \\
\text { REPORT NUMBER } \\
\text { E-17932 }\end{array}$ \\
\hline \multirow{2}{*}{\multicolumn{5}{|c|}{$\begin{array}{l}\text { 9. SPONSORING/MONITORING AGENCY NAME(S) AND ADDRESS(ES) } \\
\text { National Aeronautics and Space Administration } \\
\text { Washington, DC 20546-0001 }\end{array}$}} & $\begin{array}{l}\text { 10. SPONSORING/MONITOR'S } \\
\text { ACRONYM(S) } \\
\text { NASA }\end{array}$ \\
\hline & & & & & $\begin{array}{l}\text { 11. SPONSORING/MONITORING } \\
\text { REPORT NUMBER } \\
\text { NASA/TM-2012-217233 }\end{array}$ \\
\hline \multicolumn{6}{|c|}{$\begin{array}{l}\text { 12. DISTRIBUTIONIAVAILABILITY STATEMENT } \\
\text { Unclassified-Unlimited } \\
\text { Subject Category: } 31 \\
\text { Available electronically at http://www.sti.nasa.gov } \\
\text { This publication is available from the NASA Center for AeroSpace Information, 443-757-5802 }\end{array}$} \\
\hline \multicolumn{6}{|c|}{ 13. SUPPLEMENTARY NOTES } \\
\hline \multicolumn{6}{|c|}{$\begin{array}{l}\text { 14. ABSTRACT } \\
\text { The National Aeronautics and Space Administration (NASA) Glenn Research Center (GRC) Plum Brook Station (PBS) Space Propulsion } \\
\text { Research Facility, commonly referred to as B-2, is NASA's third largest thermal vacuum facility. It is the largest designed to store and } \\
\text { transfer large quantities of liquid hydrogen and liquid oxygen, and is perfectly suited to support developmental testing of chemical } \\
\text { propulsion systems as well as fully integrated stages. The facility is also capable of providing thermal-vacuum simulation services to } \\
\text { support testing of large lightweight structures, Cryogenic Fluid Management (CFM) systems, electric propulsion test programs, and other } \\
\text { In-Space propulsion programs. A recently completed integrated system test demonstrated the refurbished thermal vacuum capabilities of the } \\
\text { facility. The test used the modernized data acquisition and control system to monitor the facility during pump down of the vacuum chamber, } \\
\text { operation of the liquid nitrogen heat sink (or cold wall) and the infrared lamp array. A vacuum level of } 1.3 \times 10^{-4} \mathrm{~Pa}\left(1 \times 10^{-6} \text { torr) was }\right. \\
\text { achieved. The heat sink provided a uniform temperature environment of approximately } 77 \mathrm{~K}\left(140{ }^{\circ} \mathrm{R}\right) \text { along the entire inner surface of the } \\
\text { vacuum chamber. The recently rebuilt and modernized infrared lamp array produced a nominal heat flux of } 1.4 \mathrm{~kW} / \mathrm{m}^{2} \text { at a chamber } \\
\text { diameter of } 6.7 \mathrm{~m} \text { ( } 22 \mathrm{ft} \text { ) and along } 11 \mathrm{~m}(36 \mathrm{ft}) \text { of the chamber's cylindrical vertical interior. With the lamp array and heat sink operating } \\
\text { simultaneously, the thermal systems produced a heat flux pattern simulating radiation to space on one surface and solar exposure on the } \\
\text { other surface. The data acquired matched pretest predictions and demonstrated system functionality. }\end{array}$} \\
\hline \multicolumn{6}{|c|}{$\begin{array}{l}\text { 15. SUBJECT TERMS } \\
\text { Vacuum; Vacuum chamber; Solar constant; Thermal simulation; Cryogenic fluids; Heat sink }\end{array}$} \\
\hline \multicolumn{3}{|c|}{ 16. SECURITY CLASSIFICATION OF: } & $\begin{array}{l}\text { 17. LIMITATION OF } \\
\text { ABSTRACT }\end{array}$ & $\begin{array}{l}\text { 18. NUMBER } \\
\text { OF }\end{array}$ & $\begin{array}{l}\text { 19a. NAME OF RESPONSIBLE PERSON } \\
\text { STI Help Desk (email:help@sti.nasa.gov) }\end{array}$ \\
\hline $\begin{array}{l}\text { a. REPORT } \\
\text { U }\end{array}$ & $\begin{array}{l}\text { b. ABSTRACT } \\
\text { U }\end{array}$ & $\begin{array}{l}\text { C. THIS } \\
\text { PAGE } \\
\text { U }\end{array}$ & $\mathrm{UU}$ & $\begin{array}{l}\text { PAGES } \\
16\end{array}$ & $\begin{array}{l}\text { 19b. TELEPHONE NUMBER (include area code) } \\
443-757-5802\end{array}$ \\
\hline
\end{tabular}



